$\begin{array}{rr}\text { FIT(PPATOLOGI } & \text { Volume 9, Nomor 2, April 2013 } \\ \text { I N DONES IA } & \text { Halaman 39-46 } \\ \text { ISSN: } 2339-2479 & \text { DOI: } 10.14692 / \text { ji. } 9.2 .39\end{array}$

\title{
Laju Infeksi Ganoderma pada Empat Kelas Tekstur Tanah
}

\author{
Infection Rate of Ganoderma at Four Soil Texture Classes
}

\author{
Agus Susanto*, Agus Eko Prasetyo, Sri Wening \\ Pusat Penelitian Kelapa Sawit, Medan 20158
}

\begin{abstract}
ABSTRAK
Penyakit busuk pangkal batang yang disebabkan oleh Ganoderma merupakan penyakit paling merusak di perkebunan kelapa sawit di Indonesia. Perkembangan penyakit ini cepat dan berat pada tanah miskin unsur hara, khususnya yang banyak mengandung fraksi pasir. Penelitian dilaksanakan untuk mengetahui laju infeksi Ganoderma secara kuantitatif di tanah yang mengandung fraksi pasir. Perlakuan terdiri atas lima medium tanam campuran antara tanah mineral $(\mathrm{M})$ dan pasir $(\mathrm{P})$ : A (100\% $\mathrm{M}-0 \% \mathrm{P})$, B (75\% M-25\% P), C (50\% M-50\% P), D (25\% M-75\% P), dan E (0\% M-100\% P). Semua medium tanam dianalisis sifat fisika, kimia, dan biologinya. Hasil analisis menunjukkan bahwa medium tanam terdiri atas 4 kelas tekstur tanah: lempung liat berpasir untuk perlakuan $\mathrm{A}$, lempung berpasir untuk perlakuan $\mathrm{B}$, pasir berlempung untuk perlakuan $\mathrm{C}$, dan pasir untuk perlakuan D dan E. Medium tanam dengan tekstur pasir mempunyai populasi mikroorganisme tanah yang lebih rendah $\left(<1 \times 10^{6} \mathrm{cfu} \mathrm{g}^{-1}\right.$ tanah $)$ daripada medium bertekstur lempung yang mempunyai populasi $3 \times 10^{6} \mathrm{cfu} \mathrm{g}^{-1}$ tanah. Laju infeksi Ganoderma pada medium tanam pasir ialah 1.77-1.83 tanaman per bulan per 100 tanaman. Laju infeksi Ganoderma di medium tanam pasir ini lebih cepat munculnya dan lebih tinggi kejadiannya dibandingkan dengan di medium tanam bertekstur lempung.
\end{abstract}

Kata kunci: busuk pangkal batang, kelapa sawit, tanah pasir

\begin{abstract}
Basal stem rot disease caused by Ganoderma is the most destructive disease in oil palm plantation in Indonesia. Development of this disease is faster and heavier in nutrient poor soils, such as sandy soil. The objective of this research is to study and quantitatively measure the infection rate of Ganoderma disease in sandy soil. The treatments consisted of five different mixtures of mineral soil (M) and sand (P) i.e: A (100\% M-0\% P), B (75\% M- $25 \% \mathrm{P}), \mathrm{C}(50 \% \mathrm{M}-50 \% \mathrm{P}), \mathrm{D}(25 \% \mathrm{M}-75 \% \mathrm{P})$, and $\mathrm{E}(0 \%$ M-100\% P). Physical, chemical, and biological properties of each soil mixture treatment were analyzed. Soil texture can be differentiated into sandy clay loam, sandy loam, loamy sand, sand for treatmen A, B, C, D, E, respectively. Sandy soil medium had less microorganism population $\left(<1 \times 10^{6} \mathrm{cfu} \mathrm{g}^{-1} \mathrm{soil}\right)$ than sandy clay loam which microrganism population was $3 \times 10^{6} \mathrm{cfu} \mathrm{g}^{-1}$ soil. The infection rate of Ganoderma in sandy soils was $1.77-1.83$ palm per month per 100 palms. Infection rate of Ganoderma in sandy soil was faster and higher than those in loamy soil.
\end{abstract}

Key words: basal stem rot, oil plam, sandy soil

*Alamat penulis korespondensi: Pusat Penelitian Kelapa Sawit, Jalan Brigjen Katamso No. 51, Medan 20158 Tel: 061-7862477, Faks: 061-7862488, Surel: marihat_agus@yahoo.com 


\section{PENDAHULUAN}

Kondisi penyakit busuk pangkal batang yang disebabkan oleh Ganoderma saat ini berbeda dengan kondisi beberapa dekade yang lalu atau pada awal pengusahaan perkebunan kelapa sawit. Perubahan terjadi pada aspek kejadian penyakit dan distribusi, gejala dan patogenisitas, dan epidemi penyakit. Secara umum, penyakit menjadi lebih berat dan laju infeksinya semakin cepat. Distribusi penyakit ini sudah menyebar di seluruh Indonesia, meskipun dengan kejadian penyakit yang bervariasi. Tidak hanya di tanah mineral, perkembangan penyakit busuk pangkal batang juga cepat di tanah gambut.

Saat ini banyak dilaporkan bahwa pada tanah yang relatif miskin unsur hara cenderung mempunyai kejadian penyakit busuk pangkal batang yang besar. Akumulasi kejadian penyakit sangat didukung substrat yang melimpah, yaitu tanaman kelapa sawit yang selalu tersedia dan inang alternatif patogen yang juga sangat luas. Fakta lain ialah sampai saat ini tidak ada kelapa sawit yang resisten atau imun terhadap Ganoderma boninense.

Oleh sebab itu, penyakit busuk pangkal batang ( $G$. boninense) digolongkan menjadi penyakit penting yang menyebabkan kehilangan hasil secara luas pada perkebunan kelapa sawit, terutama di Malaysia (Paterson 2007; Naher et al. 2013).

Saat ini banyak dilaporkan bahwa pada tanah yang relatif miskin unsur hara terutama tanah pasir cenderung mengalami kejadian penyakit busuk pangkal batang yang lebih besar. Pada beberapa tempat di Indonesia, kebun yang bersebelahan dengan kondisi bertanah pasir mengalami kejadian penyakit yang tinggi.

Penelitian ini menghitung secara kuantitatif laju infeksi penyakit busuk pangkal batang pada tanah pasir secara simulasi di pembibitan kelapa sawit. Dengan mengetahui laju infeksi penyakit busuk pangkal batang pada berbagai sifat fisik dan kimia tanah diharapkan faktor predisposisi dan epidemi penularan dapat ditentukan sehingga membantu mengendalikan penyakit busuk pangkal batang kelapa sawit.

\section{BAHAN DAN METODE}

Penelitian dilaksanakan di laboratorium dengan material tanaman yang digunakan adalah varietas komersial kelapa sawit DxP. Isolat Ganoderma yang digunakan sebagai sumber inokulum adalah isolat Aek Pancur, Sumatera Utara yang selama ini teruji mempunyai patogenisitas tinggi melalui uji pendahuluan.

\section{Produksi Inokulum Ganoderma}

Ganoderma dalam bentuk sumber inokulum diperbanyak pada substrat kayu karet berukuran $6 \mathrm{~cm} \times 6 \mathrm{~cm} \times 6 \mathrm{~cm}$. Teknik penggunaan kayu karet sebagai sumber inokulum Ganoderma sebagai berikut. Potongan kayu karet dibersihkan kulitnya menggunakan mesin serut. Sebanyak lima potongan kayu karet dimasukkan ke dalam kantong plastik tahan panas dan ditutup dengan kapas dan kertas. Kayu karet disterilkan menggunakan autoklaf pada suhu $121{ }^{\circ} \mathrm{C}$ tekanan 1 atm selama 30 menit. Setelah didinginkan potongan kayu karet tersebut diinokulasi secara aseptik dengan potongan Ganoderma dalam medium potato dextrose agar (PDA) sebesar $1 \mathrm{~cm} \times 1 \mathrm{~cm}$. Inkubasi pada suhu $29{ }^{\circ} \mathrm{C}$ dilakukan selama 60 hari untuk mendapatkan inokulum yang sudah cukup tua (Idris et al. 2004).

\section{Medium Tanam dan Perlakuan}

Medium tanam yang digunakan sebagai uji laju infeksi Ganoderma adalah tanah mineral dari kedalaman 0-30 cm dan tanah pasir sungai. Kedua jenis tanah ini dicampur dengan komposisi medium tanam antara tanah mineral (M) dan pasir (P); A (100\% M-0\% P), B $(75 \% \quad \mathrm{M}-25 \% \quad \mathrm{P}), \mathrm{C}(50 \% \quad \mathrm{M}-50 \% \mathrm{P})$, D $(25 \% \mathrm{M}-75 \% \mathrm{P})$, dan E (0\% M-100\% P) (Tabel 1).

Sifat fisika dan kimia kelima medium tanam perlakuan selanjutnya dianalisis di laboratorium menggunakan prosedur standar di laboratorium analisis tanah Pusat Penelitian Kelapa Sawit. Karakteristik sifat fisik meliputi fraksi pasir, debu, dan liat; sifat kimia meliputi $\mathrm{pH}$, kandungan $\mathrm{C}$, $\mathrm{N}$, rasio $\mathrm{C} / \mathrm{N}, \mathrm{P}$, dan $\mathrm{K}$. 
Tabel 1 Perlakuan medium tanam pada berbagai komposisi tanah mineral dan pasir

\begin{tabular}{ccc}
\hline \multirow{2}{*}{ Perlakuan } & \multicolumn{2}{c}{ Komposisi medium tanam } \\
\cline { 2 - 3 } & Tanah mineral (\%) & Pasir $(\%)$ \\
\hline A & 100 & 0 \\
B & 75 & 25 \\
C & 50 & 50 \\
D & 25 & 75 \\
E & 0 & 100 \\
\hline
\end{tabular}

Semua sampel tanah dianalis tekstur tanahnya dengan metode hidrometri. Kemasaman tanah diukur dengan $\mathrm{pH}$ meter yang bekerja secara potensiometeri. C-organik sampel dianalisis dengan metode Wakley and Black, nitrogen total dengan metode Kjeldahl. Analisis P tersedia dilakukan dengan metode Bray 1 dan analisis K dengan metode AAS. Masingmasing sifat kimia, fisika, dan biologi tanah dari sampel dikelompokkan menggunakan nilai harkat standar unsur hara (Tabel 2), sifat fisik dan biologi (Tabel 3).

Rancangan percobaan yang digunakan adalah rancangan acak lengkap. Satu petak percobaan terdiri atas 5 tanaman, masingmasing petak percobaan diulang 4 kali.

\section{Inokulasi Bibit Tanaman}

Teknik inokulasi menggunakan metode sitting germinated seed. Satu inokulum Ganoderma dalam rubber wood block berumur 2-3 bulan diletakkan di dalam kantong plastik ukuran $40 \mathrm{~cm} \times 50 \mathrm{~cm}$ yang berisi tanah dengan kedalaman $5 \mathrm{~cm}$ di bawah titik penanaman kecambah kelapa sawit. Kecambah kelapa sawit segera ditanam bersamaan dengan pada saat inokulasi Ganoderma. Pembibitan menggunakan sistem naungan paranet dengan intensitas sinar $70 \%$ selama percobaan. Pemeliharaan bibit terdiri atas penyiraman dan perawatan sesuai dengan standar pemeliharaan bibit sampai umur 6 bulan. Pemupukan selama penelitian ditiadakan agar tidak mempengaruhi laju infeksi Ganoderma.

\section{Pengamatan Kejadian Penyakit Busuk Pangkal Batang}

Pengamatan kejadian penyakit busuk pangkal batang dilakukan setiap bulan selama 6 bulan percobaan. Perkembangan kejadian penyakit busuk pangkal batang diamati berdasarkan gejala dan tanda penyakit secara visual. Gejala penyakit berupa daun mengering dan nekrosis serta kematian

Tabel 2 Sifat kimia medium tanam

\begin{tabular}{ccccccc}
\hline Perlakuan & $\mathrm{pH}$ & $\mathrm{C} / \mathrm{N}$ & $\mathrm{P}(\mathrm{ppm})$ & \multicolumn{2}{c}{$\begin{array}{c}\mathrm{K} \\
(\mathrm{me} / 100 \mathrm{~g})\end{array}$} \\
\hline $\mathrm{A}$ & $4.90 \begin{array}{c}\text { agak masam } \\
\text { (agak rendah) }\end{array}$ & 3.33 rendah & 3.00 & rendah & 0.20 & agak rendah \\
$\mathrm{B}$ & $5.06 \begin{array}{c}\text { agak masam } \\
\text { (agak rendah) }\end{array}$ & 6.00 agak rendah & 3.66 & rendah & 0.21 & agak rendah \\
$\mathrm{C}$ & $5.43 \begin{array}{c}\text { agak masam } \\
\text { (agak rendah) }\end{array}$ & 5.00 agak rendah & 4.00 & rendah & 0.66 & sedang \\
$\mathrm{D}$ & $5.60 \begin{array}{c}\text { agak masam } \\
\text { (agak rendah) }\end{array}$ & 7.00 agak rendah & 6.00 & rendah & 0.14 & rendah \\
E & $7.00 \begin{array}{c}\text { agak basa } \\
\text { (agak tinggi) }\end{array}$ & 5.00 agak rendah & 10.00 agak rendah & 0.80 & agak tinggi \\
\hline
\end{tabular}

Tabel 3 Sifat fisika dan biologi medium tanam

\begin{tabular}{ccrrcc}
\hline Perlakuan & Pasir (\%) & Debu (\%) & Liat (\%) & Tekstur & $\begin{array}{c}\text { Populasi cendawan } \\
\text { dan bakteri } \\
\text { (cfu g-1 tanah) }\end{array}$ \\
\hline A & 56.00 & 12.33 & 31.33 & Lempung liat berpasir & $3 \times 10^{6}$ \\
B & 73.00 & 8.33 & 18.66 & Lempung berpasir & $1 \times 10^{6}$ \\
C & 83.00 & 7.66 & 9.33 & Pasir berlempung & $<1 \times 10^{6}$ \\
D & 91.66 & 2.33 & 6.00 & Pasir & $<1 \times 10^{6}$ \\
E & 99.00 & 1.00 & 0.00 & Pasir & $<1 \times 10^{6}$ \\
\hline
\end{tabular}


tanaman, sedangkan tanda penyakit berupa tubuh buah Ganoderma yang muncul pada batang bibit kelapa sawit. Kejadian Penyakit (KP) Ganoderma dihitung dengan rumus:

$$
\mathrm{KP}=\frac{\mathrm{a}}{\mathrm{a}+\mathrm{b}} \times 100 \% \text {, dengan }
$$

$\mathrm{KP}$, kejadian penyakit; a, jumlah tanaman sakit; b, jumlah tanaman sehat.

Pada akhir penelitian dilakukan pengamatan gejala nekrotik akar akibat serangan Ganoderma dengan cara pembongkaran bibit kelapa sawit. Pengamatan untuk memastikan gejala penyakit busuk pangkal batang yang ada di bawah permukaan medium tanam.

\section{Pengamatan Tinggi Tanaman Bibit Kelapa Sawit}

Pengamatan tinggi tanaman bibit kelapa sawit dilakukan untuk mendukung data pengaruh kejadian penyakit busuk pangkal batang terhadap bibit kelapa sawit. Tinggi tanaman diukur dari permukaan tanah sampai dengan ujung daun tertinggi dengan interval pengamatan setiap 2 bulan.

\section{Populasi Mikroorganisme Tanah}

Pada akhir penelitian dilakukan pengamatan populasi mikroorganisme tanah menggunakan metode pengenceran. Bakteri dihitung pada medium nutrient agar (NA), sedangkan cendawan pada medium PDA.

\section{Analisis Data}

Penyakit busuk pangkal batang adalah penyakit dengan tipe monosiklik. Oleh karena itu, laju infeksi (R) dihitung dengan rumus van der Plank, yaitu:

$$
\mathrm{X}=\mathrm{Q} \times \mathrm{R} \times \mathrm{t} \text {, dengan }
$$

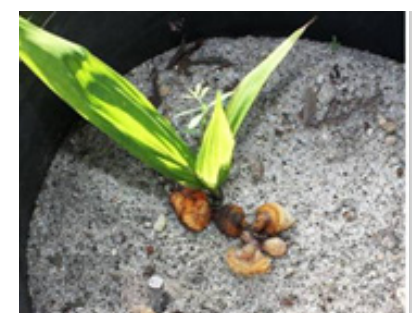

a

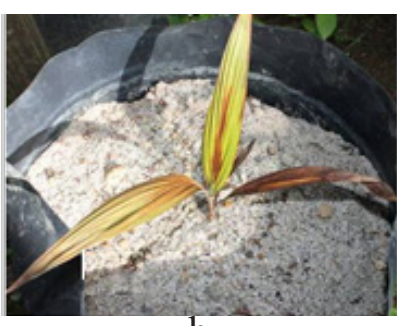

b
$\mathrm{X}$, kejadian penyakit setelah berlangsungnya epidemi; Q, kejadian penyakit pada awal dari penyakit yang berbanding lurus dengan inokulum awal; R, laju infeksi adalah kecepatan penambahan jumlah tanaman sakit pada populasi tanaman per unit per satuan waktu; t, waktu berlangsungnya epidemi.

Kejadian penyakit busuk pangkal batang, tinggi tanaman, dan laju infeksi dianalisis dengan analisis sidik ragam. Selain itu juga dilakukan uji lanjut menggunakan Duncan multiple range test pada taraf 5\% menggunakan program SAS versi 9.0.

\section{HASIL}

Gejala visual penyakit busuk pangkal batang muncul pertama kali pada tiga bulan setelah inokulasi Ganoderma. Gejala visual penyakit busuk pangkal batang ialah nekrosis pada helaian daun dan mengering yang diikuti kematian bibit kelapa sawit. Sebagian besar bibit kelapa sawit juga menunjukkan tanda penyakit berupa tubuh buah Ganoderma yang muncul pada pangkal batang (Gambar 1). Kejadian penyakit busuk pangkal batang pertama kali muncul pada bulan ke-3, yaitu perlakuan B dan D, berturut-turut sebesar 5\% dan $15 \%$. Pada bulan ke-6, kejadian penyakit tertinggi pada tanah bertekstur pasir (D dan E), yaitu sebesar 55\% dan 50\% (Gambar 2). Kejadian penyakit pada tanah lempung (A) baru muncul pada bulan ke-6 setelah diamati dengan pembongkaran gejala nekrotik akar.

Berdasarkan hasil pengamatan gejala visual dan nekrotik akar pada bulan ke-6 setelah inokulasi, kejadian penyakit busuk pangkal batang di tanah tekstur pasir lebih tinggi

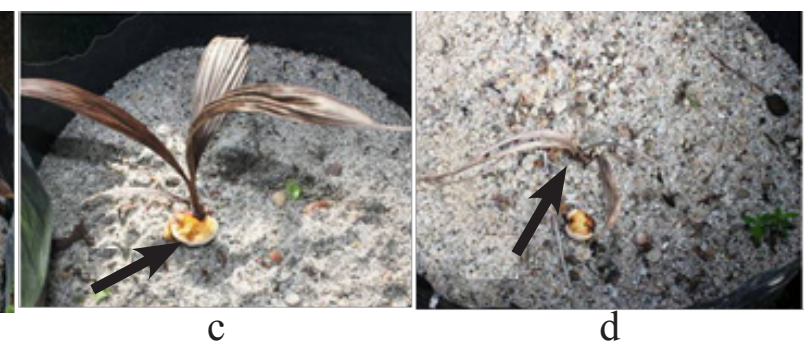

Gambar 1 Perkembangan gejala kematian bibit kelapa sawit karena Ganoderma di medium tanam pasir. a, daun menguning; b, gejala awal nekrosis; c, nekrosis berat dan muncul tubuh buah Ganoderma; dan d, bibit kelapa sawit mati. 
daripada tanah tekstur lempung (Gambar 2). Dengan demikian, secara garis besar medium tanam yang dicoba dapat dikelompokkan menjadi 2 kelompok tekstur, yaitu pasir dan lempung. Kejadian penyakit busuk pangkal batang pada tekstur pasir sebesar 50\% dan $55 \%$, sedangkan pada tekstur tanah pasir berlempung sebesar $25 \%$. Kejadian penyakit pada tekstur lempung liat berpasir dan lempung berpasir lebih rendah, yaitu 10\% (Tabel 4).

Tinggi rendahnya kejadian penyakit busuk pangkal batang pada medium tanam perlakuan sangat dipengaruhi oleh sifat fisik, $\mathrm{pH}$ tanah dan biologi tanah. Semakin tinggi persentase fraksi pasir tanah akan semakin meningkatkan kejadian penyakit busuk pangkal batang. Kemasaman tanah paling rendah dimiliki oleh perlakuan A, yaitu sebesar 4.9 dan $\mathrm{pH}$ tertinggi dimiliki perlakuan E, yaitu sebesar 7.0, sedangkan perlakuan lain mempunyai kategori $\mathrm{pH}$ yang hampir sama, yaitu agak masam. Sifat kimia lain, yaitu $\mathrm{C} / \mathrm{N}$, ketersedian hara $\mathrm{P}$ dan $\mathrm{K}$ tidak mempunyai perbedaan yang mencolok (Tabel 2). Rasio $\mathrm{C} / \mathrm{N}$ semua perlakuan menunjukkan nilai agak rendah. Demikian juga untuk ketersediaan hara $\mathrm{P}$, semua medium tanam perlakuan menunjukkan nilai yang sama, yaitu rendah sampai agak rendah. Ketersedian hara $\mathrm{K}$ dapat dikelompokkan menjadi dua kelompok besar. Tekstur tanah lempung mempunyai ketersediaan hara $\mathrm{K}$ agak rendah, sedangkan tekstur pasir menunjukkan ketersediaan rendah sampai agak tinggi.

Sifat biologi tanah atau medium tanam sangat mempengaruhi perkembangan penyakit busuk pangkal batang. Populasi bakteri dan cendawan sangat berbeda antara tanah dengan tekstur pasir dan lempung. Pada medium tanah dengan tekstur pasir populasi bakteri dan cendawan sangat rendah, yaitu kurang dari $1 \times 10^{6} \mathrm{cfu} \mathrm{g}^{-1}$ tanah, sedangkan pada tanah tekstur lempung lebih dari $1 \times 10^{6} \mathrm{cfu} \mathrm{g}^{-1}$ tanah, bahkan untuk tekstur lempung liat berpasir mempunyai populasi bakteri dan cendawan yang relatif tinggi, yaitu $3 \times 10^{6} \mathrm{cfu} \mathrm{g}^{-1}$ tanah (Tabel 3). Cendawan yang berhasil diisolasi pada medium tanam ini adalah Trichoderma sp., Rhizopus sp., Penicillium sp., dan Alternaria sp.

Tinggi bibit kelapa sawit sangat tertekan oleh sifat tanah maupun keberadaan patogen Ganoderma. Tinggi tanaman pada tekstur pasir relatif lebih rendah dibandingkan dengan perlakuan lainnya (A, B, dan C) (Tabel 4). Laju infeksi Ganoderma pada medium tanam tekstur pasir sebesar 1.77 dan 1.83 tanaman per bulan sehingga dapat diartikan pada 100 tanaman kelapa sawit akan bertambah sekitar 2 tanaman sakit setiap bulannya. Sedangkan pada tanah tekstur lempung, laju infeksinya lebih lambat.

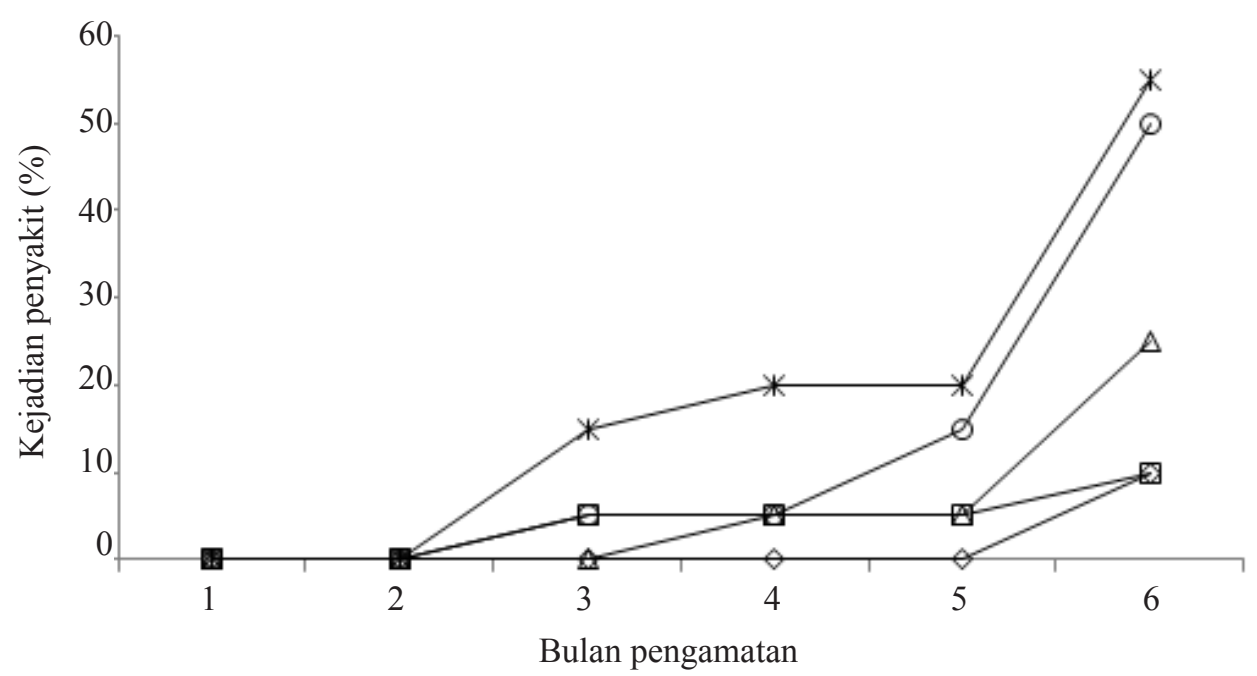

Gambar 2 Perkembangan kejadian penyakit busuk pangkal batang oleh Ganoderma pada berbagai medium tanam. $\_$, A (Lempung liat berpasir); $\sqsubset$, B (Lempung berpasir); $\triangle$, C (Pasir berlempung); $\rightarrow$, D (Pasir); $\multimap$, E (Pasir). 
Tabel 4 Tinggi tanaman kelapa sawit, laju infeksi dan kejadian penyakit busuk pangkal batang pada berbagai medium tanam pada bulan keenam setelah inokulasi Ganoderma

\begin{tabular}{cccc}
\hline Perlakuan & $\begin{array}{c}\text { Tinggi tanaman } \\
(\mathrm{cm})\end{array}$ & $\begin{array}{c}\text { Laju infeksi }(\mathrm{R}) \\
\text { per bulan }\end{array}$ & $\begin{array}{c}\text { Kejadian penyakit } \\
(\%)\end{array}$ \\
\hline $\mathrm{A}$ & $51.71 \mathrm{a}$ & $0.50 \mathrm{~d}$ & $10 \mathrm{c}$ \\
$\mathrm{B}$ & $52.68 \mathrm{a}$ & $0.75 \mathrm{c}$ & $10 \mathrm{c}$ \\
$\mathrm{C}$ & $46.56 \mathrm{~b}$ & $1.50 \mathrm{~b}$ & $25 \mathrm{~b}$ \\
$\mathrm{D}$ & $36.92 \mathrm{c}$ & $1.77 \mathrm{a}$ & $55 \mathrm{a}$ \\
E & $37.46 \mathrm{c}$ & $1.83 \mathrm{a}$ & $50 \mathrm{a}$ \\
\hline
\end{tabular}

Angka yang diikuti huruf yang berbeda pada kolom yang sama menunjukkan hasil berbeda nyata pada uji selang ganda Duncan $\alpha 0.05$

\section{PEMBAHASAN}

Ganoderma merupakan cendawan Basidiomycota yang bersifat tular tanah dan sebagai penyebab utama penyakit akar putih pada tanaman berkayu dengan menguraikan lignin. Sebagian besar siklus Ganoderma ada di dalam tanah atau jaringan tanaman. Penularan penyakit busuk pangkal batang melalui tiga cara, yaitu kontak akar tanaman dengan sumber inokulum Ganoderma, udara dengan basidiospora, dan inokulum sekunder berupa tunggul tanaman atau inang alternatif.

Perkembangan penyakit busuk pangkal batang di tanah gambut lebih cepat daripada di tanah mineral. Laju infeksi yang lebih cepat ini diduga karena peran mekanisme selain penyebaran Ganoderma melalui basidiospora (Sanderson 2005). Gejala penyakit busuk pangkal batang yang muncul di tanah gambut tidak hanya busuk pangkal batang, tetapi juga busuk pangkal atas (Susanto et al. 2008).

Spesies Ganoderma yang patogen pada kelapa sawit mempunyai kisaran inang yang luas. Pada habitat alami di hutan, cendawan ini dapat menyerang tanaman berkayu. Selain menyerang Elaeis guineensis dan Albizia sp., $G$. boninense dapat menyerang anggota palma yang lain, seperti Cocos nucifera, Livistona subglobosa, Casuarina tolurosa, dan Areca spp. Di daerah pantai ada dua spesies palma yang dapat menjadi sumber penularan penyakit ini, yaitu nibung (Oncosperma filamentosa) dan serdang (Livistona cochichineasis) (Turner 1981).

Penularan penyakit busuk pangkal batang melalui tanah dan kontak akar sangat dipengaruhi sifat fisik, kimia, dan biologi tanah. Laporan awal menyebutkan bahwa penyakit busuk pangkal batang banyak terjadi pada daerah pantai (pasir) (Gurmit 1991), tetapi laporan terakhir menyebutkan bahwa busuk pangkal batang banyak terjadi di daerah pantai maupun daerah pedalaman. Demikian juga untuk jenis tanah, Turner (1981) melaporkan bahwa penyakit busuk pangkal batang jarang ditemukan di tanah gambut dan menurut Benjamin dan Chee (1995) serangan berat banyak terjadi pada tanah laterit.

Lahan dengan tekstur tanah berpasir mempunyai kecenderungan kejadian penyakit busuk pangkal batang yang lebih besar. Hal ini sangat dipengaruhi sifat matriks tanah (Chang 2003). Kecepatan laju infeksi Ganoderma di tanah pasir disebabkan sifat fisik tanah pasir yang longgar atau porositas tinggi sehingga akar tanaman akan lebih cepat bergerak menuju sumber inokulum Ganoderma. Sifat kimia tanah yang mempengaruhi laju infeksi Ganoderma di dalam tanah ialah $\mathrm{pH}$. Berdasarkan uji laboratorium, G. boninense dapat tumbuh pada $\mathrm{pH}$ 3.0-8.5 dengan suhu optimal $30^{\circ} \mathrm{C}$ dan terganggu pertumbuhannya pada suhu 15 dan $35^{\circ} \mathrm{C}$, serta tidak dapat tumbuh pada suhu $40{ }^{\circ} \mathrm{C}$ (Abadi dan Dharmaputra 1988).

Faktor lain yang mempengaruhi laju infeksi Ganoderma pada tanah pasir adalah populasi mikroorganisme di dalam tanah. Tanah pasir relatif mempunyai populasi mikroorganisme yang lebih sedikit. Rizosfer tanah mineral banyak mengandung bakteri dan cendawan. Salah satu jenis cendawan yang sering ditemukan ialah Trichoderma sp. yang sudah banyak digunakan sebagai agens pengendali hayati untuk penyakit busuk pangkal batang. Trichoderma menekan 
patogen Ganoderma melalui kompetisi ruang dan nutrisi, produksi enzim kitinase dan glukanase, dan hiperparasit melalui lilitan hifa atau miselium. Salah satu jenis bakteri yang mampu menekan penyakit busuk pangkal batang kelapa sawit ialah bakteri endofit (Zaiton et al. 2006, 2008). Semua bakteri dan cendawan di daerah rizosfer saling berinteraksi dengan G. boninense (Abdullah et al. 2005).

Faktor penentu lainnya ialah kesuburan tanah pasir. Tanah yang miskin unsur hara akan menyebabkan tanaman menurun daya tahannya terhadap infeksi patogen. Tanaman yang lemah akan mudah terinfeksi patogen. Lemahnya tanaman ini dapat disebabkan karena kurangnya hara bagi tanaman. Pemberian unsur $\mathrm{Cu}$ dan $\mathrm{Ca}$ dapat mengurangi kejadian penyakit di pembibitan kelapa sawit (Nursabrina et al. 2012). Peningkatan mekanisme ketahanan tanaman kelapa sawit ini melalui proses pembentukan lignin yang meningkat sehingga mampu mengurangi degradasi lignin oleh patogen (Paterson et al. 2009), dengan demikian penggunaan enzim penghambat seharusnya juga dapat mencegah degradasi lignin tanaman (Paterson et al. 2008).

Oleh karena itu, strategi pengendalian pada tanah pasir harus menerapkan prinsip epidemiologipenyakittulartanah. Strategiyang dilakukan dalam mengendalikan Ganoderma mirip dengan yang diterapkan untuk penyakit tular tanah lainnya yang umumnya sulit untuk ditangani. Strategi yang paling efektif ialah dengan cara mengurangi inokulum awal, tetapi penurunan laju infeksi bersifat komplementer. Sumber utama inokulum Ganoderma terdapat di akar dan batang kelapa sawit yang terinfeksi Ganoderma. Cara terbaik untuk mengendalikan Ganoderma dilakukan dengan sanitasi bagian tanaman yang merupakan tempat sumber inokulum. Pengendalian sumber inokulum Ganoderma sangat penting untuk menekan penyakit busuk pangkal batang kelapa sawit. Selain itu, penting juga memanipulasi populasi mikroorganisme tanah pasir dengan berbagai perlakuan misalnya pemberian bahan organik.

\section{DAFTAR PUSTAKA}

Abadi AL, Dharmaputra OS. 1988. Pengaruh pHmediumdan suhu terhadap pertumbuhan miselium Ganoderma boninense. Laporan tahunan kerja sama penelitian Pusat Penelitian Marihat-Biotrop tahun 1988. Bogor (ID): Biotrop.

Abdullah F, Rusli MH, Sebran N. 2005. Bacteria from oil palm agricultural system and their interactions with Ganoderma boninense and Trichoderma harzianum. Pertanika J Trop Agric Sci. 28(2):95-102.

Benjamin M, Chee KH. 1995. Basal stem rot of oil palm - a serious problem on inland soils. MAPPS-Newletter. 19:1-3.

Chang TT. 2003. Effect of soil moisture content on the survival of Ganoderma species and other wood inhabiting fungi. Plant Dis. 87(10):1201-1204. DOI: http://dx.doi.org/ 10.1094/PDIS.2003.87.10.1201.

Gurmit S. 1991. Ganoderma the scourge of oil palm in the coastal areas. Planters 67(786):421-444.

Idris AS, Kushairi A, Ismail S, Ariffin D. 2004. Selection for partial tolerance in oil palm progenies to Ganoderma basal stem rot. Journal of Oil Palm Res. 16:12-18.

Naher L, Yusuf UK, Ismail A, Tan SG, Mondal MMA. 2013. Ecological status of Ganoderma and basal stem rot disease of oil palms (Elaeis guineensis Jacq). AJCS. 7(11):1723-1727.

Nursabrina AA, Sariah M, Zaharah AR. 2012. Suppression of basal stem rot disease progress in oil palm (Elaeis guineensis) after copper and calcium supplementation. Pertanika J Trop Agric Sci. 35(S):13-24.

Paterson RRM. 2007. Ganoderma disease of oil palm: A white rot perspective necessary for integrated control. Crop Prot. 26:13691376. DOI: http://dx.doi.org/10.1016/j. cropro.2006.11.009.

Paterson RRM, Meon S, Abidin MAZ, Lima N. 2008. Prospects for inhibition of lignin degrading enzymes to control Ganoderma white rot of oil palm. Curr Enz Inhib. 4:172-179. DOI: http://dx.doi. org/10.2174/157340808786733613. 
Paterson RRM, Meon S, Lima N. 2009. The feasibility of producing oil palm with altered lignin content to control Ganoderma disease. J Phytopathol. 157:649-656. DOI: http://dx.doi.org/10.1111/j.1439-0434. 2009.01553.x.

Sanderson FR. 2005. An insight into spore dispersal of Ganoderma boninense on oil palm. Mycopathology. 159:139-141. DOI: http://dx.doi.org/10.1007/s11046-0044436-2.

Susanto A, Ginting PA, Surianto, Prasetyo AE. 2008. Pola penyebaran Ganoderma boninense pada perkebunan kelapa sawit (Elaeis guineensis) di lahan gambut: studi kasus di PT Anak Tasik Labuhan Batu Sumatera Utara. J Peneli Kelapa Sawit. 16:135-146.
Susanto A, Purba RY, Sudharto. 2005. Enhancing biological control of basal stem rot disease (Ganoderma boninense) in oil palmplantations. Mycopathology. 159:153157. DOI: http://dx.doi.org/10.1007/s11046004-4438-0.

Turner PD. 1981. Oil Palm Diseases and Disorders. Oxford (US): Oxford University Press.

Zaiton S, Sariah M, Abidin MAZ. 2006. Isolation and characterization of microbial endophytes from oil palm roots: implication as biocontrol agents against Ganoderma. Planters. 82(966):587-597.

Zaiton S, Sariah M, Abidin MAZ. 2008. Effect of endophytic bacteria on growth and suppression of Ganoderma infection in oil palm. IJAB. 10(1):27-32. 